\title{
India's geodynamic evolution during the Eocene: perspectives on the origin and early evolution of modern mammal orders
}

\author{
${ }^{1 *}$ Department of Earth Sciences, Indian Institute of Technology, Roorkee 247667, India \\ ${ }^{2}$ Birbal Sahni Institute of Palaeosciences, Lucknow 226007, India \\ *Corresponding author; Email: sunil.bajpai@es.iitr.ac.in
}

(Received : 30/01/2019; Revised accepted : 11/09/2019)

https://doi.org/10.18814/epiiugs/2020/020031

In recent years, explosion of research in the early Tertiary mammals of India has attracted widespread interest because of the importance of this fauna in understanding biogeographic origins, early evolution, and dispersal patterns of several modern mammal orders as well for its paleogeographic implications. Although Paleocene mammals are yet to be discovered in the Indian subcontinent, Indian Early Eocene mammal faunas are now becoming increasingly important in debates concerning the origins of several modern terrestrial orders. In many cases, Eocene mammals from India represent primitive and stratigraphically oldest records in the entire Cenozoic of South Asia, and also gain significance because they closely coincide in age with the withdrawal of the Neotethys, initiation of India-Asia collision and the intense warming intervals during the Paleocene-Eocene Thermal Maximum (PETM) and the Early Eocene. The Eocene fossil record from India also provides compelling evidence in support of an Indian origin (Out-of-India hypothesis) for some of the major orders of modern marine and terrestrial mammals, particularly Cetacea and Perissodactyla, whose antiquity can now be traced to the Indian taxa. In addition, several key taxa discovered in India provide significant insights into the early diversification of primates, artiodactyls, and sirenians.

\section{Introduction}

The Late Cretaceous-Eocene terrestrial vertebrate assemblages from the Indian subcontinent are of great importance in our understanding of the degree of isolation of the Indian subcontinent and the resulting biotic endemism as well as dispersal during this interval. The fossil biota from this interval encompasses the interval from India's last phase of northward drift until its suturing with Asia. In recent years it has been shown to represent three distinct biogeographic domains: Gondwanan, Laurasian, and the endemic component. These components present major biogeographic puzzles and have led to hypotheses that emphasize the fact that the distribution of terrestrial fossil biota provides compelling evidence for the reconstruction of paleogeographic relationships between the landmasses (e.g., Ali and Aitchison, 2008; Chatterjee et al., 2017; Kapur and Khosla, 2018).

The northern (Laurasian) land masses (North America/Europe/ China) have been historically considered to be the centre of placental evolution because of their rich fossil records from the Paleocene and Eocene. However, following several important discoveries during the past quarter of a century, India has emerged as one of the most important centres for possible origination/early diversification of some of the major orders of modern placental mammals (Bajpai et al., 2009; Chatterjee et al., 2017).

In the Indian subcontinent, the oldest (pre-Cenozoic) records of eutherian mammals are mostly restricted to isolated teeth and postcranial elements of the adapisoriculid mammal Deccanolestes from the Deccan intertrappean beds of latest Cretaceous age (Prasad et al., 1994; Goswami et al., 2011). Recent phylogenetic analysis of combined dental and tarsal characters show that adapisoriculids represent the basal eutherians, with Deccanolestes (the oldest known adapisoriculid) being a sister taxon of the Early Paleogene Afrodon from Africa (Goswami et al., 2011).

The post-Cretaceous records in India come from the Early Eocene deposits (Cambay Shale) of the lignite mines around Vastan, in the Surat District of Gujarat State, western India. Coeval deposits in Pakistan have also yielded a rich fauna of Early Eocene mammals. The Vastan fauna, which is the earliest known Cenozoic mammal fauna in the Indian subcontinent, appears to coincide with the age of initiation of India-Asia collision and the earliest Eocene global warming events (e.g., Clyde et al., 2003; Clementz et al., 2010).

The Vastan fauna includes a rich and diverse assemblage of stem groups of several orders of terrestrial mammals including 
perissodactyls, primates, and artiodactyls (the APP taxa). Several mammal orders, including the APP taxa, appeared almost simultaneously across the northern continents during the intense warming interval at PETM ( 55.5 Ma), but the place of their origin and immediate ancestors have long been controversial (e.g., Gingerich, 2006). It is becoming increasingly apparent that during the Early Eocene, as India converged withAsia, it carried the stem groups of many modern mammals that later dispersed to northern continents (the Out-of-India hypothesis; Krause and Maas, 1989). In addition, the spectacular fossil record of marine mammals, especially archaeocetes, from the Indian subcontinent has already established that this landmass was the centre of origin and early evolution of whales (Bajpai et al., 2009; Thewissen et al., 2009). The geographic origins of many other tetrapod taxa have not yet been identified, but recent discoveries point to India as a principal centre for their taxonomic origination. This article summarizes the recent work on Eocene mammals of India and highlights its importance in our understanding of the origin and early evolutionary history of several extant mammal orders, both terrestrial and marine.

\section{Paleocene-Early Eocene records}

Although no Paleocene mammals are yet known from the Indian subcontinent, the occurrence of adapisoriculids such as Deccanolestes in the Late Cretaceous Deccan intertrappean beds points to the early radiation of eutherian mammals in India. Interestingly, adapisoriculids have also been found recently in the earliest Eocene deposits of India (Kapur et al., 2017a, 2017b), indicating a continuation of this lineage for more than 10 million years after the Deccan volcanic episode during the terminal Cretaceous-earliest Paleocene. Future discoveries from the Paleocene will likely shed new light on the origin and explosive evolution of placental mammals during the earliest Eocene in India, which have attracted considerable global attention in recent years as discussed below. Potential mammal-yielding Late Paleocene horizons may be found in the future at the base of the lignite sequences of western India.

Two main areas in the Indian subcontinent, one in India and the other in Pakistan, have yielded a diversity of Early Eocene mammals. The Pakistani sites are in the Baluchistan Province and include the coal mines near the city of Quetta. Early Eocene mammals have been described from the coal-bearing Ghazij Formation and the younger Mami Khel Formation in the western part of Pakistan, which record a dramatic shift from marine to continental depositional regimes (Gingerich et al., 1997; Missiaen and Gingerich, 2012, 2014). Assemblages of large mammals from the Ghazij Formation ( 50-54 Ma) are dominated by endemic quettacyonids and cosmopolitan tillodonts in the middle part of the formation, but an increasingly cosmopolitan fauna is represented by tillodonts, perissodactyls, primates, and artiodactyls of Holarctic affinities in the upper part of the formation (Clyde et al., 2003; Missiaen and Gingerich, 2014).

The Early Eocene mammal-yielding sites in India are in Gujarat State, where the most productive horizon is the Cambay Shale in the open-cast lignite mines at Vastan and nearby areas. Early Eocene mammals are also known from the type section of the Subathu Formation (KutharNala) in the NW Himalaya region of Himachal Pradesh. These mammal faunas appear abruptly approximately 10 million years after the Deccan intertrappean mammal fauna of Maastrichtian age. The mammal zone in the Cambay Shale is sandwiched between Eocene Thermal Maximum 2 (ETM2) and the Paleocene-Eocene Thermal Maximum (PETM), which makes them possibly the oldest ( 54.5 Ma) known Cenozoic mammals of South Asia. However, the relative ages of the oldest Indian and Pakistan mammal-bearing sites are equivocal.

The Vastan terrestrial mammal fauna comprises over 10 diverse orders including artiodactyls (Bajpai et al., 2005a; Kumar et al., 2010), perissodactyls (Bajpai et al., 2005a, 2006a; Rose et al., 2007, 2014; Kapur and Bajpai, 2015), primates (Bajpai et al., 2005b, 2007, 2008; Rose et al., 2009, 2018), creodonts (Bajpai et al., 2009c; Rana et al., 2015), lagomorphs (Rose et al., 2008), rodents (Bajpai et al., 2007; Rana et al., 2008), bats (Smith et al., 2007), tillodonts (Rose et al., 2009), condylarths (Bajpai et al., 2009), apatotherians, proteutherians (Bajpai et al., 2005a) and possible marsupials (Bajpai et al., 2005c). The last-named group is represented by the poorly known genus Indodelphis. The Vastan section has yielded not only a wellpreserved fauna of placental mammals, but also fish, frogs, squamates, birds, ostracods, foraminifera, insects in amber, and plant remains preserved in a low-energy, coastal marsh-bay complex of mangrove swamps under ahumid climate (Prasad et al., 2013 and references therein).

Marine mammal faunas of Early Eocene age are rare in India. The only known record is Himalayacetus from the Subathu Formation of the Simla Hills in Himachal Pradesh (NW Himalaya), commonly considered to be the oldest known whale, approximately 53.5 million years old (Bajpai and Gingerich, 1998). Himalayacetus is based on fragmentary material and its familial status is uncertain, although it was originally described as a pakicetid. Himalayacetus is significant in that it predates the terrestrial Pakicetus and its contemporaries by at least $\sim 3.5$ m.y. Oxygen isotope composition of tooth enamel of Himalayacetus suggests that it lived both in fresh and salt water. The Himalayacetus - yielding horizon represents a shallow benthic depositional environment, suggesting that some whales were partially marine very early in the course of their evolution.

\section{Middle Eocene records ( 48-42 Ma)}

The next younger terrestrial mammal fauna in the Indian subcontinent has long been known from the early Middle Eocene ( 48Ma) deposits in NW Himalaya, especially from the Subathu Formation (Himachal Pradesh and Jammu \& Kashmir states) of north India, and the correlative sequences in Pakistan (reviewed in Thewissen et al., 2001). Several taxa within the Subathu mammalian assemblage record the establishment of stable dispersal corridors between India and Asia, as indicated by the appearance of large mammals of Asian affinity such as rhinoceroses and brontotheres. This interval also saw the endemic diversification of certain groups like anthracobunid perissodactyls and raoellid artiodactyls. The former group has recently been removed from Tethytheria and reinterpreted as stem perissodactyls along with cambaytheres (Cooper et al., 2014), whereas the latter family (raoellids), represented by the semi-aquatic Indohyus, is closely tied to the origin of whales, as a sister taxon to the Order Cetacea.

The Middle Eocene marine mammal fauna from India, comprising fossil cetaceans and sirenians, is mainly known from the Kutch (Kachchh) region of Gujarat State (western India) where it occurs in the Harudi Formation of Middle Eocene (Late Lutetian, 42 Ma) age (Sahni and Mishra, 1975; Bajpai et al., 1996, 2004, 2009; Thewissen and Bajpai, 2009). Eocene cetaceans in Kutch are found in a variety 
of marine environments including tidal flats, coastal swamps, reefs and seagrass meadows.

The foregoing account clearly shows that an explosive radiation of mammals, especially placental mammals, took place in India during the Early Eocene during the hyperthermal events around the Paleocene-Eocene boundary ( 55 Ma), as India became a new member of the Holarctic faunal province in the wake of initiation of the IndiaAsia collision. Thus, several taxa of Gondwanan heritage which were previously restricted to India migrated into Eurasia. On the other hand, many species previously restricted to Eurasia moved into India, making India a crossroad for faunal migrations. What follows is a brief summary of important discoveries that have a significant bearing on the origins and early evolutionary histories of some of the major extant mammalian orders.

\section{Cetacea (whales, dolphins, porpoises)}

In recent years, fossil finds from the Indian subcontinent spanning the interval from $\sim 42-48$ Ma have elucidated one of the best understood examples of macroevolution: the origin of whales from four-footed land mammals (Fig.1). The initial steps of this major evolutionary transition from a land mammal to obligate marine predators have been substantially documented by the Eocene cetacean families of the Indian subcontinent: Pakicetidae, Ambulocetidae, Remingtonocetidae, Protocetidae as well as their artiodactyl sister group, the Raoellidae, which is only known from Pakistan and India. Raoellids were small racoon-sized artiodactyls (even-toed ungulates) and their important synapomorphies with archaic cetaceans (archaeocetes) include the presence of an involucrum, anteroposterior arrangement of incisors in the jaw, and high crowns in the posterior premolars (Thewissen et al., 2007). Oxygen isotope data suggests a semi-aquatic life style of Indohyus (Thewissen et al., 2009; Cooper et al., 2016). Furthermore, in spite of its archaic molar morphology, Indohyus had dental wear facets that resemble those of archaeocetes (Thewissen et al., 2011).

The fossil record from the Indian subcontinent has allowed a comprehensive study of the evolution of the various organ systems involved in whale origins, including locomotion, hearing, balance, feeding, and osmoregulation (Bajpai et al., 2009). It has been documented that the transition from life on land to life in the sea took place among the Eocene archaeocetes. Six families of archaeocetes: pakicetids (Pakicetus, Ichthyolestes, and Nalacetus), ambulocetids (Ambulocetus, Gandakasia, and possibly Himalayacetus), remingtonocetids (Remingtonocetus, Kutchicetus, Andrewsiphius, Dalanistes, Attockicetus), protocetids (Indocetus, Babiacetus, Kharodacetus, Dhedacetus, Rodhocetus, Artiocetus, Maiacetus, and Takracetus), dorudontids, and basilosaurids have been described from the Indo-Pakistan region. These differ significantly in their habitats, which varied from land to freshwater, to coastal waters, to fully marine. The first three families (pakicetids, ambulocetids, and remingtonocetids) are known mainly from the Middle Eocene of the Indo-Pakistan region and provide critical insights into the origin and early radiation of whales with resulting improvement in locomotor and hearing systems (Bajpai et al., 2009c). Pakicetids, the most archaic whales with long slender limbs and a long narrow tail are only known from a few localities in northwestern India and northern Pakistan (Thewissen et al.,2009). Like raoellids, pakicetids had aquatic adaptations for wading in shallow freshwater, and like raoellids and all cetaceans, pakicetids have an involucrum, the thickened inner lip on the tympanic bone. Ambulocetids, next in line of archaic cetaceans, are also only known from a few localities in Pakistan and India. These whales were larger than pakicetids, and lived amphibiously (Thewissen et al., 1994, 2009). Remingtonocetids, the long-snouted archaic cetaceans largely restricted to the Middle Eocene of Indo-Pakistan, had specialized dentitions (Thewissen and Bajpai, 2001): their molars do not have crushing basins that are observed in pakicetids and ambulocetids. That they were capable of enhanced directional hearing is evidenced by their large ears set far apart on the skull. Their underwater sound transmission was also quite effective, as suggested by the large mandibular foramen (Nummela et al., 2007; Bajpai et al., 2009; Thewissen et al., 2009). Remingtonocetids also document evolution in another major sense organ, the organ of balance (Spoor et al., 2002). Protocetids have a worldwide distribution and are diverse in the morphology of their locomotor skeleton (Gingerich et al., 1994, 2001; Bajpai and Thewissen, 2014).Basilosaurids (including dorudontines), the largest of the Eocene whales, had long snake-like bodies and a tail fluke much like modern whales, and they probably swam with sinuous movements of the entire body.

Taken together, the Indo-Pak archaeocetes show an enormous morphological diversity that reflects various stages of aquatic adaptations, ranging from terrestrial pakicetids of early Middle Eocene age, via Middle Eocene semiaquatic ambulocetids, remingtonocetids and protocetids, to Middle-to-Late Eocene fully aquatic basilosaurids. Current fossil evidence clearly indicates that the origin and early evolution of cetaceans took place in the Indian subcontinent.

\section{Perissodactyla (horses, zebras, tapirs, rhinoceroses)}

After the artiodactyls, the second great living placental order of hoofed mammals is the odd-toed ungulates, or perissodactyls, the most spectacular cursorial mammals since the Eocene times. They appeared abruptly at the beginning of the Eocene across the Holarctic continents as dominant browsing herbivores, but perissodactyl diversity started to decline during the Middle Eocene. Perissodactyls split into two clades: tapiromorphs (rhinos, tapirs, and kin) and hippomorphs (horses and kin). Tapiromorpha, abundant in the Eocene faunas of East Asia, play an important role in mammalian biochronology. During the Late Eocene, artiodactyls displaced the perissodactyls as the predominant ungulates. The place of origin of perissodactyls has long been disputed.

Recent discoveries from the Vastan mine show that both perissodactyls and artiodactyls were present in the earliest Eocene of India (Bajpai et al., 2005a, 2006a; Kapur and Bajpai, 2015; also see Chatterjee et al., 2017), A new family of early perissodactyls, Cambaytheriidae, was erected recently, and it presently consists of two genera from Vastan: the type genus Cambaytherium with $C$. thewissias the type species, and Kalitheriumwith K. marinus as the type species. The discovery of Cambaytherium (Fig. 2) fills a major gap in our understanding of the origin and early evolution of the perissodactyls, and it provides a window into the common ancestry of all perissodactyls. The presence of the most basal group of perissodactyls in Vastan suggests that ancestors of rhinos, zebras, and horses may have originated in the Indian subcontinent (Krause and Maas, 1990; Cooper et al., 2014; Rose et al., 2014). Cambaytherium was about the size of a pig and likely weighed 25$30 \mathrm{~kg}$. Cambaytherium shared some features with perissodactyls, such 

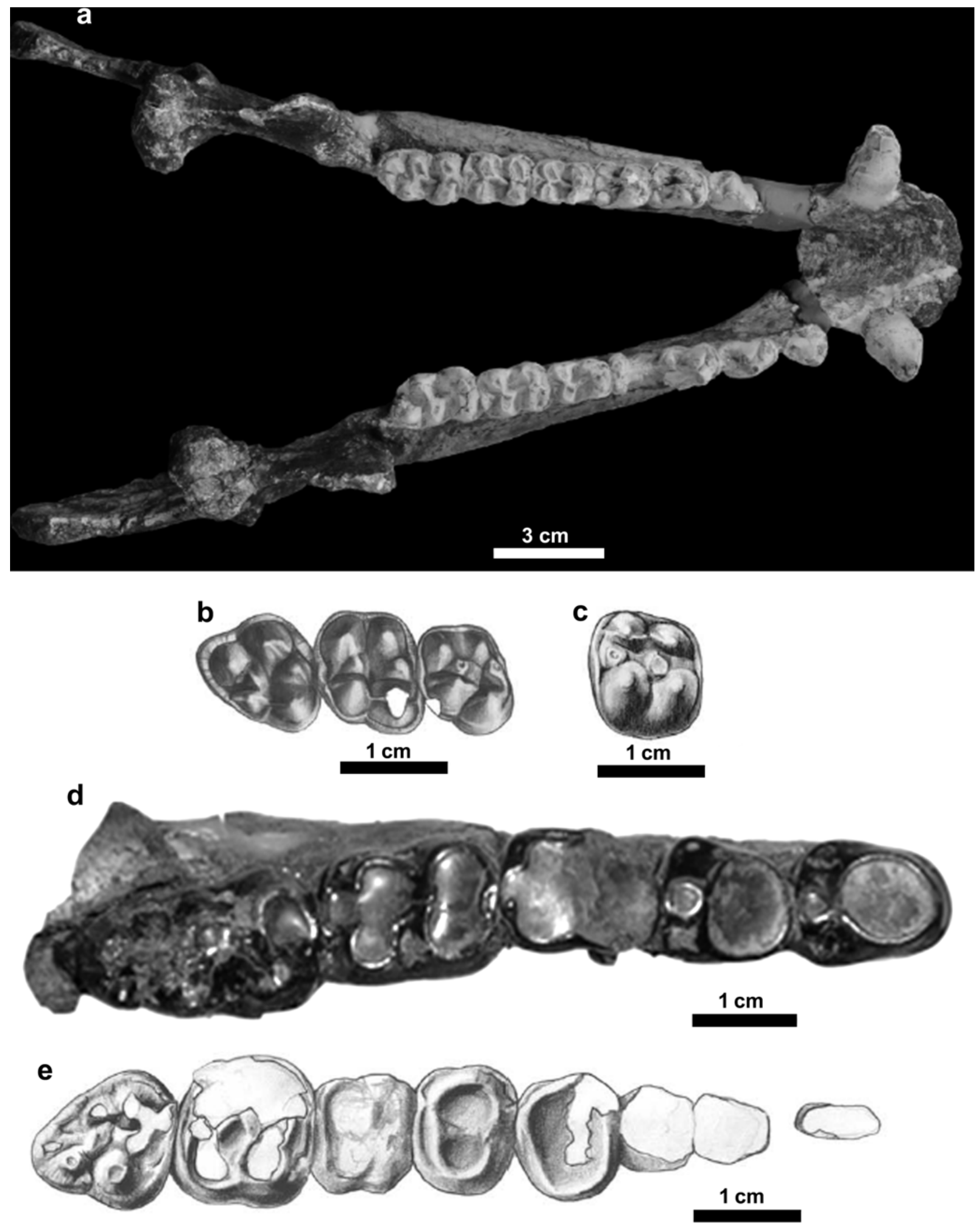

Figure 1. a, Mandible of Anthracobune wardi (H-GSP 96434; Cooper et al. 2014) from Pakistan, occlusal view; b, Molar teeth (M1-M3) of Anthracobune wardi (RR-411; Cooper et al. 2014) Jammu \& Kashmir, India, occlusal view; c, Molar tooth of Cambaytherium (IITR-SBVLM-521; Cooper et al. 2014) from Gujarat, India, occlusal view; d, Dentary of Cambaytherium (IITR/SB/VLM 503; Bajpai et al. 2005) from Gujarat, India, occlusal view; e, Rostrum of the cambaythere Kalitherium with right C-M3 (IITR-SB-VLM 931; Bajpai et al. 2006; Cooper et al. 2014) from Gujarat, India, occlusal view. 

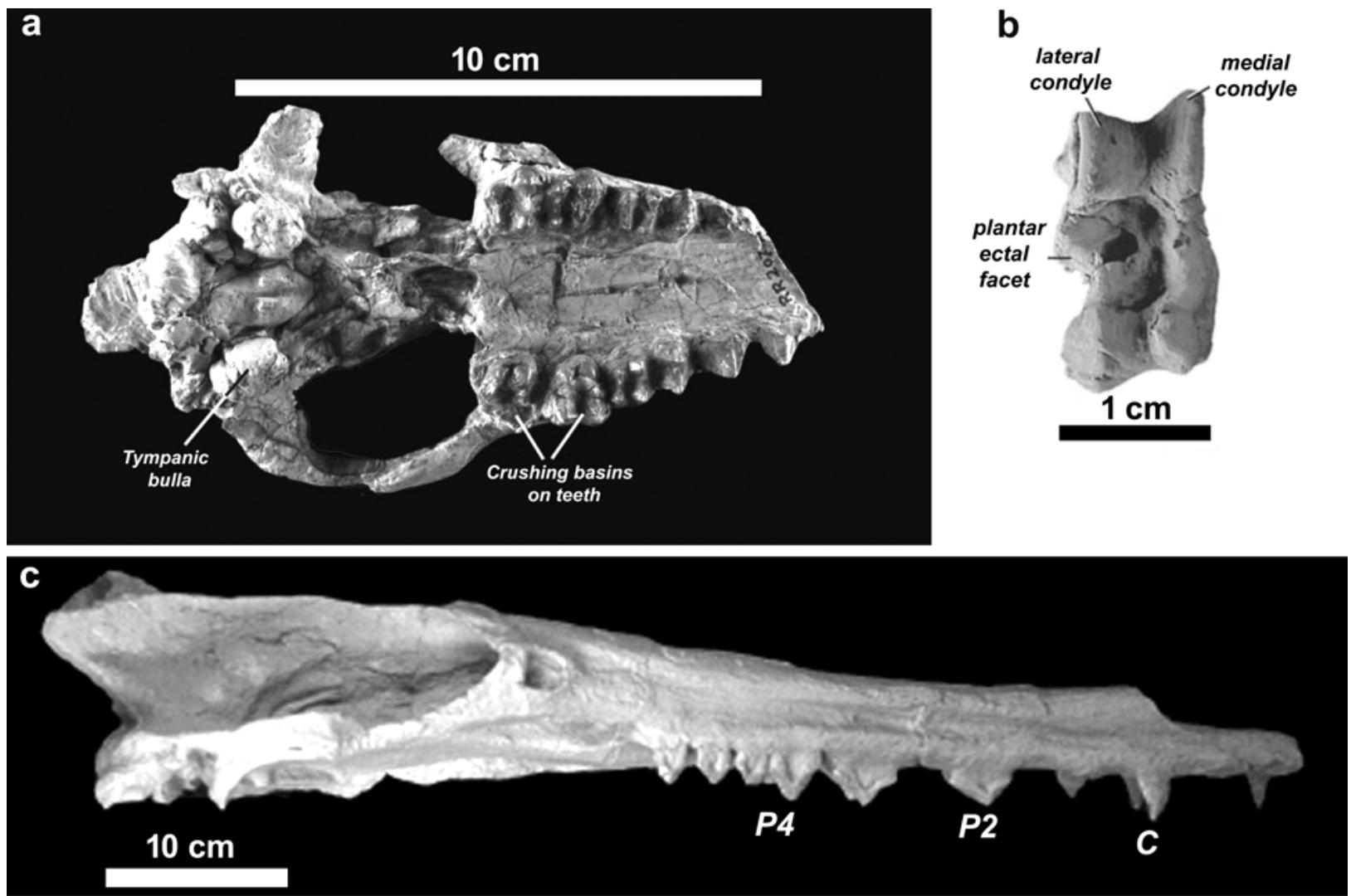

d
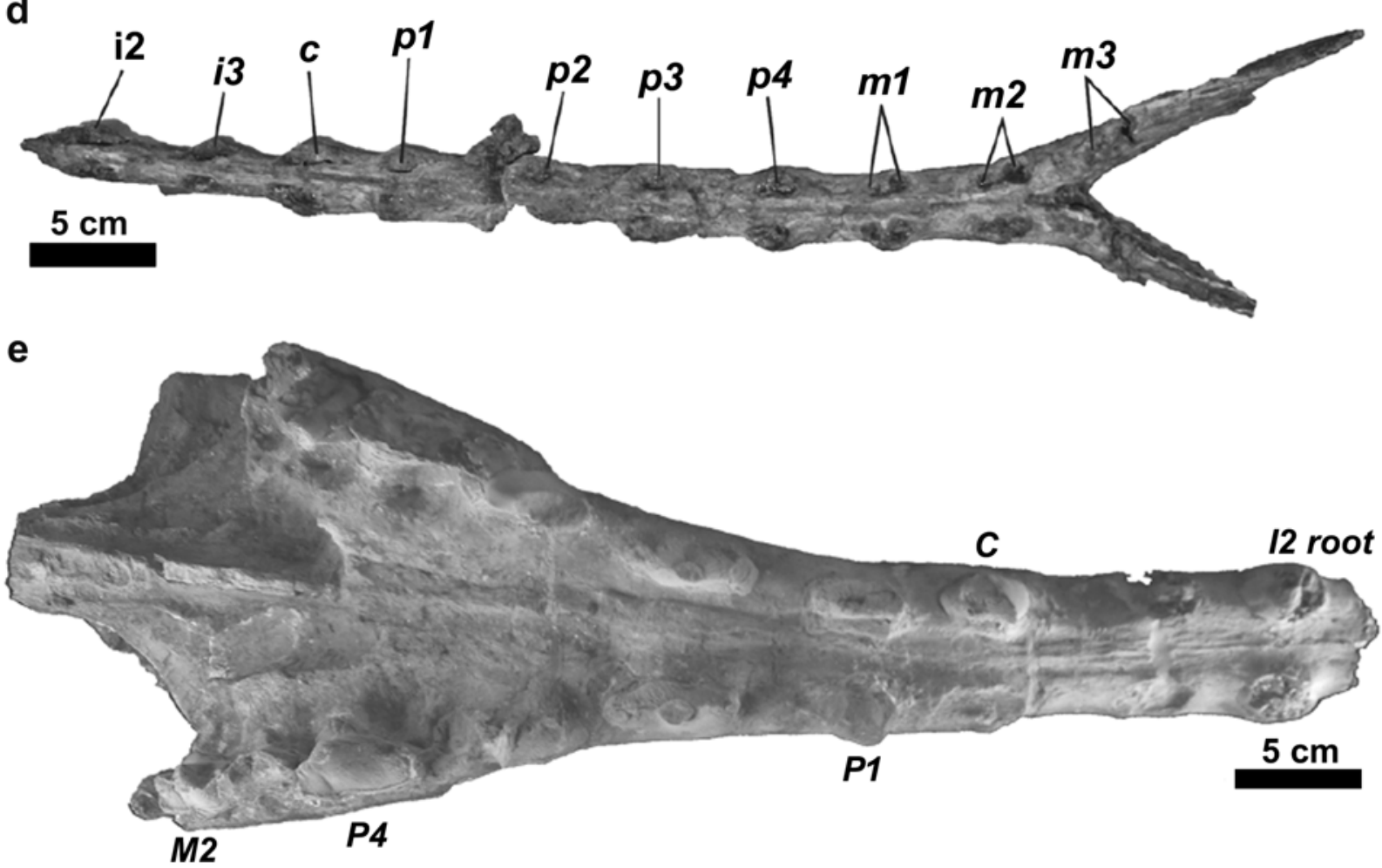

Figure. 2. a, Skull of Indohyus (RR 207; Thewissen et al. 2007), closest terrestrial relative of whales from the Eocene ( 47 Ma) Jammu \& Kashmir, NW Himalaya, India; b, Astragalus of Indohyus (RR 224; see Cooper et al. 2011); c, Skull of Remingtonocetus (IITR-SB 2770, Bajpai et al. 2011 ) from the Middle Eocene ( 42 Ma) of Kutch, Gujarat, western India, lateral view. Note the small size of eyes, and the long, narrow snout; d, Lower jaw (mandible) of Kutchicetus (IITR-SB 2636, Thewissen and Bajpai, 2009) from the Middle Eocene ( 42 Ma) of Kutch, Gujarat, western India, occlusal view. Note the long and unusually narrow mandible and fused symphysis; e, Rostrum of Kharodacetus (IITR-SB 3189, Bajpai and Thewissen, 2014), a protocetid whale from the Middle Eocene ( 42 Ma) of Kutch, Gujarat, western India, occlusal view. 
as fused lower jaw bones, derived cranio-dental traits, transverse nasofrontal suture, and similar tarsal morphology. It also had some transitional traits in common with an archaic group of hoofed mammals called phenacodontid condylarths, such as bunodont cheek teeth, robust skeleton, five metapodials, shorter tarsals, and the other bones of the hands and feet. The long-known middle Eocene European genus Hallensia, which was originally identified as a “condylarth”and later placed within Perissodactyla as a possible equoid, may instead be a cambaytheriid (Bajpai et al., 2006; Cooper et al., 2014).

The origin and early evolution of perissodactyls in the Indian subcontinent is further confirmed by the discovery of the next sister group of stem perissodactyls, called anthracobunids, from the early Middle Eocene Subathu Formation of Himalaya and the Kuldana Formation of Pakistan (Fig. 2). Anthracobunids from the Indian subcontinent include two species, Anthracobune pinfoldi and A. wardi, that show typically primitive perissodactyl features (Cooper et al., 2014). Analyses of postcranial bones and stable isotopes indicate that anthracobunids were large and lumbering, probably amphibious, and lived in marshy environments similar to environments inhabited by modern rhinos (Cooper et al., 2014). Cooper et al.'s (2014), Rose et al.'s (2014) analysis also confirmed the original identification of cambaytheres as perissodactyls and it is possible that cambaytheres may have given rise to anthracobunids. Equally significant is the recently described tapiroid from Vastan, the oldest South Asian record of this group (Kapur and Bajpai, 2015). Cambaylophus may be closely related to the long-known Chinese genus Orientolophus, indicating faunal exchange between India and Asia during the initial stage of collision.

\section{Primates}

The primates of modern aspect (euprimates) first appeared in the fossil record of North America, Europe, and Asia during the Paleocene-Eocene transition, $55.5 \mathrm{Ma}$. The simultaneous appearance of euprimates on northern continents has been intensely debated because the source area, immediate ancestors, and dispersal routes of these early primates were unknown. A high diversity of Early Eocene primates from the Indo-Pakistan region suggests that the Indian subcontinent may be an important centre for the early evolution of euprimates (Bajpai et al., 2005, 2007, 2008; Rose et al., 2009, 2018).

Two basal prosimian clades of euprimates, the lemurlike Adapoidea and the tarsier-like Omomyidae, are known from the Early Eocene of North America, Europe, and India. In contrast, the fossil record of primitive euprimates from Africa and Asia is much more limited. Recently, the Early Eocene Cambay Shale Formation has yielded a rich record of euprimates containing both adapoids (Marcgodinotius indicus, Asiadapis cambayensis, A.tapiensis, Suratius robustus) and omomyoids (Vastanomys gracilis) (Bajpai et al., 2005b, 2007; Rose et al., 2007, 2009, 2018). Omomyoids underwent their greatest diversification on northern continents during the Eocene. Adapoids probably gave rise to the strepsirrhine crown group, whereas omomyids are a probable sister taxon to anthropoids. The Indian adapoids from Vastan were initially classified in a new subfamily (Asiadapinae) of the European and North American family Notharctidae, but have since been grouped in the new family Asiadapidae (Rose et al., 2009). Co-occurrence of Adapoidea, Omomyoidea, and possibly Anthropoidea at Vastan indicates a high diversity and significant migration of early euprimates during the Early Eocene of India. Dunn et al. (2017) suggested that the Vastan euprimates could be a relic of the strepsirrhine-haplorhine divergence.

The Eocene of Pakistan has also yielded a variety of euprimates. Five Early and Middle Eocene primates, including three new adapiforms (Panobius russelli, Panobius amplior, and Sulaimania arifi) and two new omomyiforms (Indusius kaliae and Kohatius coppensi) have European affinities and suggest rapid faunal interchange between India and Europe during the Early Eocene (Gunnell et al., 2008). Panobius and Indusius are considered to have close sister taxa in Europe (Donrussellia and Melaneremia). The rest of the Pakistani and Indian Early to early Middle Eocene primate fauna also resembles European cercamonine and microchoerine euprimates much more than any East Asian or North American forms. The early diversity of euprimates in the Indian subcontinent suggests that primates may possibly have originated in India near the PETM boundary, spreading into Europe and Asia after the collision (Krause and Maas, 1990; Chatterjee et al., 2017).

\section{Sirenia (dugongs, manatees, and relatives)}

Another major group of marine mammals to which the fossil record from India has contributed significantly in recent years is the Order Sirenia (sea cows), which comprises marine herbivorous mammals with a fossil record encompassing most of the last 50 million years and most of the formerly tropical and subtropical latitudes. Well preserved and diagnostic cranial material of fossil sirenians described from the Eocene through Miocene sequences of Kutch, western India, has added significantly to our understanding of the past taxonomic and ecological diversity of this order (Bajpai et al., 1996, 2008; Thewissen and Bajpai, 2009). The Middle Eocene of Kutch has yielded several coeval taxa of sirenians, two protosirenids (Ashokia antique and Protosiren sp.) and two more derived dugongids (Eosiren sp. and Eotheroides babiae) (Bajpai et al., 2006, 2009). Protosirenids are more derived than prorastomids but more primitive than trichechids or dugongids. The Eocene of Pakistan has also yielded two species of Protosiren: P.eothene and P. sattaensis. The Kutch sirenian fauna, with Eotheroides, Eosiren, and Protosiren, plus Ashokia, a new relative of the Libyan protosirenid Libysiren sickenbergi (Bajpai et al., 2009b; Domning et al., 2017), resembles the fauna from North Africabut shows little affinity with European faunas, suggesting that two genetically distinct and endemic sirenian faunas evolved in relative isolation on the north shore (Europe) and south shore (North Africa and India), respectively, of the former Neotethys Seaway (Bajpai et al., 2009a). The Indian sirenians were, in part, congeneric and contemporaneous with an Egyptian fauna that may represent the earliest radiation of the dugongidclade.

An important puzzle in sirenian evolution that seems about to be resolved is the fact that although Eocene deposits in India have produced members of both the families Protosirenidae and Dugongidae (Subfamily Halitheriinae), the post-Eocene sirenians found in this region have only been dugongids of the Subfamily Dugonginae - until recently. Samonds et al. (in press) report a sirenian fauna from the Early Miocene of Madagascar that, in addition to several dugongines, includes the first evidence in the Indian Ocean of a halitheriine: the European and possibly North African species Metaxytherium krahuletzi. 


\section{Summary and Conclusions}

Around the Paleocene-Eocene boundary ( 55 Ma), there was significant faunal interchange between India and Eurasia. Although the timing of India-Asia collision is still debated, it appears likely that India made initial contact with Asia in the Early Eocene (ca. 55 $\mathrm{Ma}$ ), with suturing completed by $49 \mathrm{Ma}$. The early Eocene land mammal fauna from India nearly coincides in age with the initiation of India-Asia collision, and may potentially constrain the timing of India's first overland terrestrial faunal exchanges with Eurasia. The exact route and the timing of such exchanges are not yet resolved, but it appears that a subareal contact of some kind may have been established between these landmasses by 55 Ma (Fig. 3). The faunal interchange between India and Eurasia was a landmark

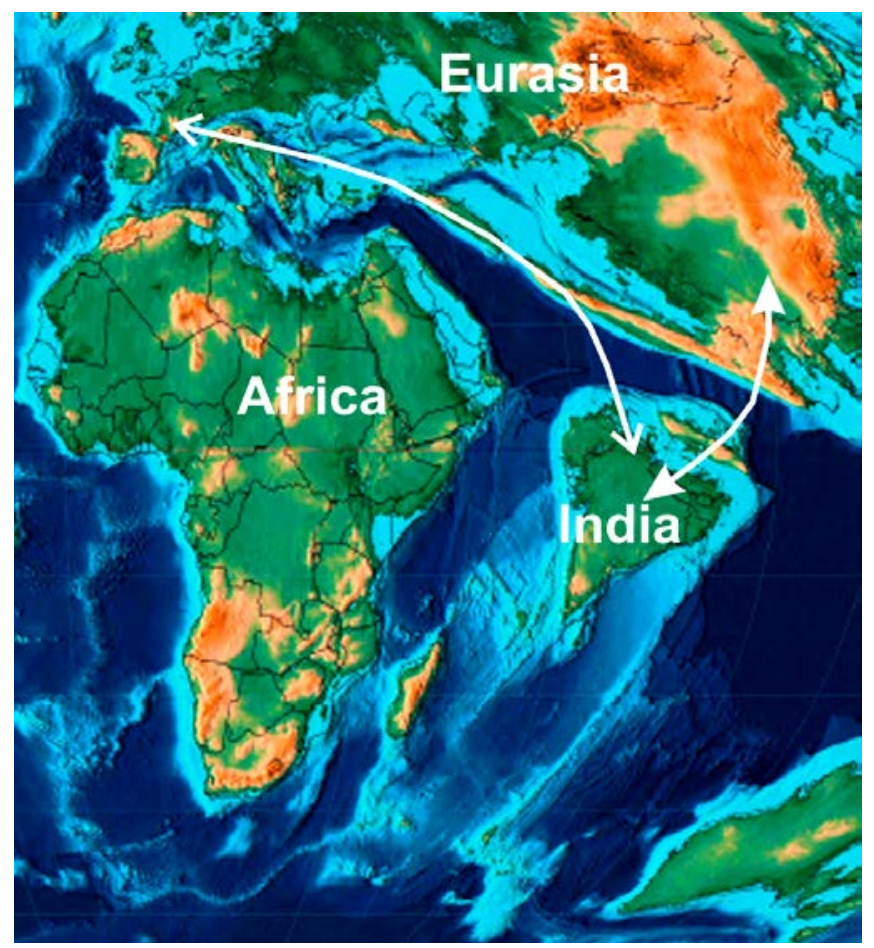

Figure 3. Paleogeographic reconstruction of India during its initial collision with Asia ( 55 Ma) showing various hypothetical routes for faunal dispersal. Dispersal of taxa between the Indian subcontinent and Eurasia possibly occurred across the Neotethys occurred via the Kohistan-Ladakh arc system (modified after Chatterjee et al. 2017).

paleobiogeographic event that led to the origin of some of the modern orders of placental mammals, supporting the Out-of-India hypothesis.

Many of the extant orders of terrestrial mammals, especially Artiodactyla, Perissodactyla, and Primates, first appear in the fossil record during the Paleocene-Eocene Thermal Event, the global warming event that marks the beginning of the Eocene. Their sudden appearance on all three northern continents (North America, Europe, and Asia) without known antecedent transitional forms, has been enigmatic and is possibly linked to dispersal in response to rapid environmental change at the beginning of PETM (Gingerich et al., 2006; Chatterjee et al., 2017). Some of the major mammalian clades from the Eocene of Indo-Pakistan have been briefly described above for a better understanding of the evolutionary and paleobiogeographic significance of this fauna. In particular, as a result of efforts made in the Indian subcontinent, especially during the past two decades and a half, the origin and evolution of whales is now one of the best documented examples of macroevolution. The fossil record from IndoPakistan, combined with an understanding of form and function in modern taxa, has allowed an understanding of the evolution of several organ systems and the underlying evolutionary processes.

Apart from whales, data on the phylogeny and stratigraphic record of several terrestrial mammal orders including perissodactyls, primates, and lagomorphs suggest a more pronounced northward migration from India to Eurasia (i.e., Out-of-India) than the southward migration from Eurasia (i.e., In-to-India). The antiquity of perissodactyls can be traced back to the genus Cambaytherium (Family Cambaytheriidae, Bajpai et al., 2005a, 2006) together with another ungulate family, Anthracobunidae, from Indo-Pakistan (Cooper et al., 2014; Rose et al., 2014). A similar scenario cannot be currently ruled out for omomyoid and adapoid euprimates, whose early history can be phylogenetically traced to the key Indian taxa Marcgodinotius, Asiadapis and Vastanomys from Vastan.

\section{Acknowledgements}

Sunil Bajpai thanks Professor G.V.R. Prasad for inviting him to contribute this article. V.V.K. would like to thank the Director, Birbal Sahni Institute of Palaeosciences (BSIP), Lucknow, for giving the necessary administrative permission. Many of the contributions discussed in this article resulted from the senior author's research projects funded by the Department of Science and Technology (DST), Government of India. V.V.K.also acknowledges funding support by the Science and Engineering Research Board (SERB), New Delhi (No. SR/FTP/ES-49/2012).

\section{References}

Ali, J.R., and Aitchison, J.C., 2008, Gondwana to Asia: Plate tectonics, paleogeography, and the biological connectivity of the Indian subcontinentfrom the Middle Jurassic through the latest Eocene (16535 Ma). Earth Science Reviews, v. 88, pp. 145-166.

Bajpai, S., 2009, Biotic perspective of the Deccan volcanism and India-Asia collision: Recent advances.In:Current Trends in Science. Bangalore, Indian Academy of Sciences Platinum Jubilee, Special Publication, pp. 505-516.

Bajpai, S., and Gingerich, P.D., 1998, A new Eocene archaeocete (Mammalia,Cetacea) from India and the time of origin of whales. Proceedings of the National Academy of Sciences of the United States of America, v. 95, pp. 15, 464-468.

Bajpai, S., and Thewissen, J.G.M., 2014, Protocetid cetaceans (Mammalia) from the Eocene of India. Palaeontologia Electronica, doi:17.3.34A

Bajpai, S., Thewissen, J.G.M., and Sahni, A., 2009, The origin and early evolution of whales:Macroevolution documented on the Indian Subcontinent. Journal of Biosciences, v. 34(5), pp. 673686.

Bajpai, S., Kapur, V.V., Das, D.P., Tiwari, B.N., Sarvanan, N., and Sahrma, R., 2005a, Early Eocene land mammals from Vastan Lignite Mine, District Surat (Gujarat), western India. Journal of the Palaeontological Society of India, v. 50, pp. 101-113.

Bajpai, S., Kapur, V.V., Thewissen, J.G.M., Tiwari, B.N., Das, D.P., Sharma, R., and Saravanan, N., 2005b, Early Eocene primates from Vastan lignite mine, Gujarat, western India. Journal of the Paleontological Society of India, v. 50, pp. 43-54. 
Bajpai, S., Thewissen, J.G.M., Kapur, V.V., Tiwari, B.N., and Sahni, A., 2006a, Eocene and Oligocene sirenians (Mammalia) from Kachchh, India. Journal of Vertebrate Paleontology, v. 26, pp. 400-410.

Bajpai, S., Kapur, V.V., Thewissen, J.G.M., Das, D.P., and Tiwari, B.N., 2006b, New Early Eocene Cambaythere (Perissodactyla, Mammalia) from the Vastan Lignite Mine (Gujarat, India) and an evaluation of Cambaythere relationships. Journal of the Paleontological Society of India, v. 51, pp. 101-110.

Bajpai, S., Kapur, V.V., Thewissen, J.G.M., Tiwari, B.N.,and Das, D.P.,2005c, First fossil marsupials from India: Early Eocene Indodelphisn. gen. and Jaegerian. gen. from Vastan lignite mine, District Surat, Gujarat. Journal of the Palaeontological Society of India, v. 50(1), pp. 147-151.

Bajpai, S., Das, D.P., Kapur, V.V., Tiwari, B.N., and Srivastava, S.S., 2007, Early Eocene rodents (Mammalia) from Vastan Lignite Mine, Gujarat, western India. Gondwana Geological Magazine, v. 22, pp. 91-95.

Bajpai, S., Kay, R.F., Williams, B.A., Das, D.P., Kapur, V.V., and Tiwari, B.N., 2008, The oldest Asian record of Anthropoidea. Proceedings of the National Academy of Sciences of the United States of America, v. 105, pp. 11093-11098.

Bajpai, S., Kapur, V.V., and Thewissen, J.G.M., 2009a, Creodont and condylarth from the Cambay Shale (Early Eocene, ca. 55-54 Ma), Vastan Lignite Mine, Gujarat, western India. Journal of the Palaeontological Society of India, v. 54, pp. 103-109.

Bajpai, S., Domning, D.P., Das, D.P., and Mishra, V.P., 2009b, A new middle Eocene sirenian (Mammalia, Protosirenidae) from India. NeuesJahrbuchfürGeologie und Paläontologie, v. 252(3), pp. 257-267.

Chatterjee, S., Goswami, A., and Scotese, C.R., 2013, The longest voyage: Tectonic, magmatic, and paleoclimate evolution of the Indian plate during its northward flight from Gondwana to Asia. Gondwana Research, v. 23, pp. 238-267.

Chatterjee, S., Scotese, C., and Bajpai, S., 2017, The restless Indian plate and its epic voyage from Gondwana to Asia: its tectonic, paleoclimatic and paleobiogeographic evolution. Geological Society of America, Special Paper, v. 529, pp. 1-147.

Clementz, M., Bajpai, S., Ravikant, V., Thewissen, J.G.M., Saravanan, N., Singh, I.B., and Prasad, V., 2010, Early Eocene warming events and the timing of terrestrial faunal exchange between India and Asia. Geology, v. 39, pp. 15-18.

Clyde, W.C., Khan, I.H., and Gingerich, P.D., 2003, Stratigraphic response and mammalian dispersal during initial India-Asia collision: Evidence from the Ghazij Formation, Balochistan, Pakistan. Geology, v. 31, pp. 1097-1100.

Cooper, L.N., Thewissen, J.G.M., Bajpai, S., and Tiwari, B.N., 2012, Morphology and locomotion of the Eocene raoellid Indohyus (Artiodactyla: Mammalia). Historical Biology, v. 24, pp. 279310.

Cooper, L.N., Seiffert, E.R., Clementz, M., Madar, S.I., Bajpai, S., Hussain, S.T., and Thewissen, J.G.M., 2014, Anthracobunids from the Middle Eocene of India and Pakistan are stem perissodactyls. PLoS One, v. 9. doi:10.1371/journal.pone.0109232

Domning, D.P., Heal, G.J.,and Sorbi,S.,2017,Libysirensickenbergi, gen. et sp. nov.: a new sirenian (Mammalia, Protosirenidae) from the middle Eocene of Libya. Journal of Vertebrate Paleontology, v. 37.doi:10.1080/02724634.2017.1299158

Gingerich, P.D., 2006, Environment and evolution through the Paleocene-Eocene thermal maximum. Trends in Ecology \& Evolution, v. 21, pp. 246-253.

Gingerich, P.D., Wells, N.A., Russell, D.E., and Shah, S.M.I., 1983, Origin of whales in epicontinental remnant seas: new evidence from the early Eocene of Pakistan. Science, v. 220, pp. 403-406.
Gingerich, P.D., Haq, M.U., Zalmout, I.S., Khan, I.H., and Malkani, M.S., 2001, Origin of whales from early artiodactyls: hands and feet of Eocene Protocetidae from Pakistan. Science, v. 293, pp. 2239-2242.

Gingerich, P.D., Arif, M., and Clyde, W.C., 1995, New archaeocetes (Mammalia, Cetacea) from the middle Eocene Domanda Formation of the Sulaiman Range, Punjab (Pakistan). Contributions from the Museum of Paleontology, University of Michigan, v. 29, pp. 291-330.

Gingerich, P.D., Abbas, S.G., and Arif, M., 1997, Early Eocene Quettacyonparachai (Condylartha) from the Ghazij Formation of Baluchistan (Pakistan): Oldest Cenozoic land mammal from South Asia. Journal of Vertebrate Paleontology, v. 17, pp. 629637.

Gingerich, P.D., Arif, M., Khan, I.H., Haq, M.U., Bloch, J.I., Clyde, W.C., and Gunnell, G.F., 2001, Gandhera quarry, a unique mammalian faunal assemblage from the early Eocene of Pakistan. In: Gunnell, G.F. (Ed.), Eocene Vertebrates: Unusual Occurrence and Rarely Sampled Habitats.Plenum Press, New York, pp. 251262.

Gingerich, P.D., Raza, S.M., Arif, M., Anwar, M., and Zhou, X., 1994, New whale from the Eocene of Pakistan and the origin of cetacean swimming. Nature, v. 368, pp. 844-847.

Goswami, A., Prasad, G.V.R., Upchurch, P., Boyer, D.M., Seiffert, E.R., Verma, O., Gheerbrant, E., and Flynn, J.J., 2011, A radiation of arboreal basal eutherian mammals beginning in the Late Cretaceous of India. Proceedings of the National Academy of Sciences of the United States of America, v. 108, pp. 1633316338.

Gunnell, G.F., Gingerich, P.D., Ul-Haq, M., Bloch, J.L., Khan, I.H., and Clyde, W.C., 2008, New primates (Mammalia) from the Early and Middle Eocene of Pakistan and their paleobiogeographical implications. Contributions from the Museum of Paleontology, University of Michigan, v. 32, pp. 1-14.

Kapur, V.V., and Bajpai, S., 2015, Oldest South Asian tapiromorph (Perissodactyla, Mammalia) from the Cambay Shale Formation, western India, with comments on its phylogenetic position and biogeographic implications. The Palaeobotanist, v. 64(1), pp. 95103.

Kapur, V.V., Das, D.P., Bajpai, S., and Prasad, G.V.R., 2017a, First mammal of Gondwanan lineage in the early Eocene of India. ComptesRendusPalevol, v. 16, pp. 721-737.

Kapur, V.V., Das, D.P., Bajpai, S., and Prasad, G.V.R., 2017b, Corrigendum to "First mammal of Gondwanan lineage in the early Eocene of India”. Kapur et al., 16(2017)]. Comptes Rendus Palevol, v. 16, pp. 820.

Kapur, V.V., and Khosla, A., 2018, Faunal elements from the Deccan volcano-sedimentary sequences of India: A reappraisal of biostratigraphic, palaeoecologic, and palaeobiogeographic spects. Geological Journal, doi:10.1002/gj.3379

Krause, D.W., and Maas, M.C., 1990, The biogeographic origins of late Paleocene-Early Eocene mammalian immigrants to the Western Interior of North America. In: Bown, T.M., and Rose, K.D. (Eds.), Dawn of the Age of Mammals in the Northern Part of the Rocky Mountain Interior, North America. Geological Society of America Special Paper, v. 243, pp. 71-105.

Kumar, K., Rose, K.D., Rana, R.S., Singh, L., Smith, T., and Sahni, A., 2010, Early Eocene artiodactyls (Mammalia) from western India. Journal of Vertebrate Paleontology, v. 30, pp. 1245-1274.

Missiaen, P., and Gingerich, P.D., 2012, New Early Eocene tapiromorph perissodactyls from the Ghazij Formation of Pakistan, with implications for mammalian biochronology in Asia. Acta Palaeontologica Polonica, v. 57, pp. 21-34.

Missiaen, P., and Gingerich, P.D., 2014, New basal Perissodactyla 
(Mammalia) from the Lower Eocene Ghazij Formation of Pakistan. Contributions from the Museum of Paleontology, University of Michigan, v. 32, pp. 139-160.

Prasad, G.V.R., Jaeger, J.J., Sahni, A., Gheerbrant, E., and Khajuria, C., 1994, Eutherian mammals from the Upper Cretaceous (Maastrichtian) intertrappean beds of Naskal, Andhra Pradesh, India. Journal of Vertebrate Paleontology, v. 14, pp. 260-277.

Prasad, V., Singh, I.B., Bajpai, S., Garg, R., Thakur, B., Singh, A., Saravanan, N., and Kapur, V.V., 2013, Palynofacies and sedimentology-based high resolution sequence stratigraphy of the lignite-bearing muddy coastal deposits (early Eocene) from Vastan lignite mine, Gulf of Cambay, India. Facies, v. 59, pp. 737-761.

Rana, R.S., Kumar, K., Escarguel, G., Sahni, A., Rose, K.D., Smith, T., Singh, H., and Singh, L., 2008, Anailuravine rodent from the lower Eocene Cambay Shale Formation at Vastan, western India, and its palaeobiogeographic implications. Acta Palaeontologica Polonica, v. 53, pp. 1-14.

Rana, R.S., Kumar, K., Zack, S.P., Sole, F., Rose, K.D., Messiaen, P., Singh, L., Sahni, A., and Smith, T., 2015, Craniodental and postcranial morphology of Indohyaenodonraoi from the early Eocene of India, and its implications for ecology, phylogeny, and biogeography of hyaenodontid mammals. Journal of Vertebrate Paleontology, v. 35 (5). doi:10.1080/02724634.2015.965308

Rose, K.D., Rana, R.S., Sahni, A., and Smith, T., 2007, A new adapoid primate from theearly Eocene of India. Contributions from the Museum ofPaleontology, University of Michigan, v. 31, pp. 379385.

Rose, K.D., DeLeon, V.B., Missiaen, P., Rana, R.S., Sahni, A., Singh, L., and Smith, T., 2008, Early Eocene lagomorph (Mammalia) from western India and the early diversification of Lagomorpha. Proceedings of the Royal Society, v. B275, pp. 1203-1208.

Rose, K.D., Rana, R.S., Sahni, A., Kumar, K., Missiaen, P., Singh, L., and Smith, T.D., 2009, Early Eocene primates from Gujarat, India. Journal of Human Evolution, v. 56, pp. 366-404.

Rose, K.D., Rana, R.S., Sahni, A., Kumar, K., Singh, L., and Smith, T., 2009, First tillodont from India: Additional evidence for an early Eocene faunal connection between Europe and India? Acta Palaeontologica Polonica, v. 54 (2), pp. 351-355.

Rose, K.D., Holbrook, L.T., Rana, R.S., Kumar, K., Jones, K.E., Ahrens, H.E., Missiaen, P., Sahni, A., and Smith, T., 2014, Early Eocene fossils suggest that the mammalian order Perissodactyla originated in India. Nature Communications, v. 5(5570). doi:10.1038/ncomms 6570

Rose, K.D., Dunn, R.H., Kumar, K., Perry, J.M.G., Prufrock, K.A., Rana, R.S., and Smith, T., 2018, New fossils from Tadkeshwar Mine (Gujarat, India) increase primate diversity from the early Eocene Cambay Shale. Journal of Human Evolution, v. 122, pp. 93-107.

Sahni, A., and Mishra, V.P., 1975, Lower Tertiary vertebrates from western India. Monograph of the Paleontological Society of India, v. 3, pp. 1-48.

Samonds, K.E., Ernat, R.A.,Andrianavalona,T., and Domning,D.P., 2018,New Miocene sirenians from Nosy Makamby, northwestern Madagascar.Journal of Vertebrate Paleontology.https://doi.org/ 10.1080/02724634.2019.1570223

Spoor, F., Bajpai, S., Hussain, S.T., Kumar, K., Thewissen, J.G.M., 2002, Vestibular evidencefor the evolution of aquatic behaviour in early cetaceans. Nature, v. 417, pp. 163-166.

Thewissen, J.G.M., and Bajpai, S., 2001, Dental morphology of Remingtonocetidae (Cetacea, Mammalia). Journal of Paleontology, v. 75(2), pp. 463-465.

Thewissen, J.G.M., and Bajpai, S., 2009, New skeletal material of Andrewsiphius and Kutchicetus, two Eocene cetaceans from India. Journal of Paleontology, v. 83(5), pp. 635-663.

Thewissen, J.G.M., Hussain, S.T., and Arif, M., 1994, Fossil evidence for the origin of aquatic locomotion inarchaeocete whales. Science, v. 263, pp. 210-212.

Thewissen J.G.M., Williams, E.M., and Hussain, S.T., 2001, Eocene mammal faunas from northern Indo-Pakistan. Journal of Vertebrate Paleontology, v. 21, pp. 347-66.

Thewissen, J.G.M., Williams, E.M., Roe, L.J., and Hussain, S.T., 2001, Skeletons of terrestrial cetaceans and the relationships of whales to artiodactyls. Nature, v. 413, pp. 277-281.

Thewissen, J.G.M., Cooper, L.N., Clementz, M.T., Bajpai, S., and Tiwari, B.N., 2007, Whales originated from aquatic artiodactyls in the Eocene epoch of India. Nature, v. 450(20), pp. 1190-1194.

Thewissen, J.G.M., Cooper, L.N., George, J.C., and Bajpai, S., 2009, From land to water: the origin of whales, dolphins, and porpoises. Evolution Education \& Outreach, v. 2, pp. 272-288.

Thewissen, J.G.M., Sensor, J.D., Clementz, M., and Bajpai, S., 2011, Evolution of dental wear and diet during the origin of whales. Paleobiology, v. 37(4), pp. 655-669.

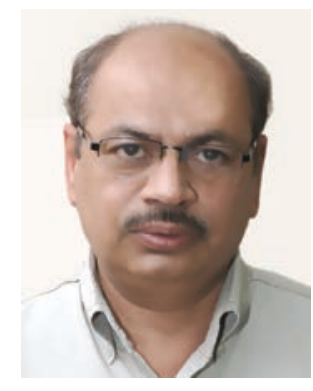

Sunil Bajpai is a paleontologist with main research interests in late Cretaceous-Tertiary biotas of India and their implications for evolution, paleobiogeography, biostratigraphy and related fields. He is currently professor at Department of Earth Sciences, Indian Institute of Technology, Roorkee. During 2013-18, he was Director of the Birbal Sahni Institute of Palaeosciences, Lucknow. Prof Bajpai has authored over 120 publications and in recognition of his research contributions, he was elected Fellow of the Indian Academy of Sciences (FASc.), the National Academy of Sciences (FNASc.). He has also been the recipient of the National Geoscience Award of the Ministry of Mines, and the National Award for Geosciences \& Technology of the Ministry of Earth Sciences, Government of India.

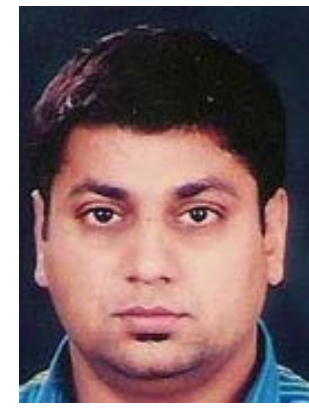

Vivesh Kapur is a palaeontologist working as Scientist ' $C$ ' at the Birbal Sahni Institute Institute of Palaeosciences (BSIP), Lucknow, India. His main interest is in Late Cretaceous-Palaeogene biota from India, with emphasis on vertebrate faunas, especially mammals, as well as associated microfaunas. 